\title{
СПІВВІДНОШЕННЯ ОГЛЯДУ 3 ОБШУКОМ У КРИМІНАЛЬНОМУ ДОСУДОВОМУ ПРОВАДЖЕННІ
}

\author{
ЛУЧКО Оксана Анатоліївна - Державна установа «Криворізька академія \\ патрульної поліції, цикл загально-правових дисциплін \\ ORCID: https://orcid.org/0000-0003-2388-055X \\ УДК 343.132 \\ DOI 10.32782/EP.2020.3.17
}

\begin{abstract}
В статье на основании анализа норм уголовного процессуального законодательства, научных исследований, судебной практики, определяются общие и отличительнъие чертьи между осмотром и объгском в уголовном досудебном производстве. Делается въивод о наличии таких общих черт между осмотром и обыском, как цель их проведения, время, способ биксаиии результатов в протоколе. Приводятся отдельные отличительнъле чертьл между осмотром и объгком. Одной из отличительньх особенностей, на которую указывает автор в статье? является обязательность и характер принуждения, которьий при проведении объгска в отличие от осмотра имеет постояннъий характер. Кроме того, возможность проведения осмотра в Единъий реестр досудебных расследований отличает его от обыска в уголовном досудебном производстве.

Ключевъе слова: осмотр, объик, цель, время, протокол, биксачия, принуждение.
\end{abstract}

\section{Постановка проблеми}

За своєю пізнавальною природою огляд має спільні риси з обшуком. «Процесуальна схожість» цих слідчих (розшукових) дій призводить то того, що одна дія проводиться під «маскою» іншої, внаслідок чого порушуються права та законні інтереси учасників кримінального досудового провадження. Тому дослідження цієї теми має не лише теоретичне, а й практичне значення.

\section{Стан дослідження проблеми}

Значний внесок у дослідження питань, пов'язаних 3 порядком проведення слідчих дій, у тому числі огляду, зробилиА.А. Благодир, В. І. Галаган, І.В. Гловюк,Б. М .Д е р д ю к, О . П . К у ч и н с ь к а , Є.Д.Аукянчиков, А.В. Мельниченко, С. М. Стахівський, В. М. Тертишник, $\lambda$. Д. Удалова та інші. Однак у правозастосовній практичці 3 цієї тематики 6 ще багато питань, які потребують більш детального й комплексного вирішення.

Метою i завданням дослідження є визначення співвідношення між оглядом та обшуком у кримінальному досудовому провадженні. Для досягнення мети автором були поставлені наступні завдання: виокремити та охарактеризувати спільні та відмінні риси між оглядом та обшуком у кримінальному досудовому провадженні.

\section{Виклад основного матеріалу}

У правозастосовчій діяльності досить поширеними $є$ випадки проведення обшуку, оформлюючи результати оглядом місця події. Так, аналізуючи виправдовувальний вирок Ставищенського районного суду Київської області від 16.01.2019 року, провадження № 1-кп/378/4/19 встановлено, що за обставинами справи працівники поліції вилучили в ОСОБИ наркотичний засіб, оформивши цю дію протоколом огляду місця події. Суд зауважив, що було фактично проведено обшук особи, а не огляд місця події [1]. 


\section{Кримінальне право, кримінальний процес та криміналістика}

Аналогічне рішення міститься у постанові Верховного Суду (далі - ВС) від 21.01.2020 року, справа № 381/2316/17, де також з ясував, що слідчий під виглядом проведення огляду місця події фактично здійснив особистий обшук ОСОБА_1 [2].

Про неприпустимість проведення обшуку під виглядом огляду місця події ВС наголошував неодноразово, зокрема у постановах від 07 червня 2018 року (справа№ 740/5066/15-к), від 26 лютого 2019 року (справа № 266/4000/14-к), від 19 березня 2019 року (справа № 380/157/14-к), від 22 травня 2019 року (справа № 640/2449/16-к). [3]

Проаналізувавши кримінальне процесуальне законодавство в частині проведення огляду та обшуку, а також думки вчених, що здійснювали наукові дослідження з цієї теми, ми виокремили спільні та відмінні ознаки даних слідчих (розшукових) дій.

Так, спільними рисами огляду та обшуку у кримінальному досудовому провадженні 6 :

1) Мета проведення. У ст.ст. 237, 234 Кримінального процесуального кодексу України (далі - КПК України) зазначено, що метою огляду, як і метою обшуку є виявлення та фіксації відомостей про обставини вчинення кримінального правопорушення. Окрім того, мета обшуку є дещо конкретизованою і формулюється також через відшукання знаряддя кримінального правопорушення або майна, яке було здобуте у результаті його вчинення, а також встановлення місцезнаходження розшукуваних осіб. Хоча і особистий обшук спрямовується на виявлення предметів чи документів, що мають значення для кримінального провадження (ч. 5 ст. 236 КПК України) [4].

У теорії кримінального процесу, науковці, аналізуючи співвідношення огляду та обшуку, по-різному визначають цю ознаку, називаючи ії «завданням», «цілями».

Так, O.I. Аитвинчук зазначає, що огляд та обшук має спільні завдання - пошук і вилучення об'єктів, які мають значення для кримінального провадження (речових доказів, документів) [5, с.5], В.В. Горошко вказує, що спільними ознаками обшуку і огляду 6 їх спрямованість на збір і перевірку доказів у кримінальному провадженні, що свідчить про їх пізнавальний характер та спільність цілі - спрямованість на виявлення слідів злочину та майна, інших предметів і документів, які мають або можуть мати значення для кримінального провадження [6, с. 132].

Ми вважаємо, що незалежно від назви цієї ознаки - «ціль», «завдання», «спрямованість», чи «мета», як це визначено у КПК України, сама суть цих двох дій є спільною - їх гносеологічна (пізнавальна) природа, скерованість на виявлення та фіксацію інформації про обставини кримінального правопорушення.

2) Протокольна борма біксащиі. Фіксація результатів огляду, як і обшуку, полягає у складанні протоколу. Причому незалежно від застосування технічних засобів фіксації (фото- чи відеозапису) при їх проведенні, у КПК України не передбачено спрощений порядок фіксації результатів, як це зазначено щодо допиту, який фіксується технічними засобами (ч. 3 ст. 104 КПК України) [4].

На нашу думку, складання протоколу як способу оформлення результатів огляду, так і обшуку, має бути у формі протоколу в обов'язковому порядку, незалежно від використання при ньому технічних засобів. Як слушно зазначає I.M. Бацько, формування протоколів включає, з одного боку, віддзеркалення встановлених у процесі слідства фактичних даних про обставини розслідуваної події, а 3 іншого - відповідну процесуальну форму і встановлений для неї порядок фіксації і посвідчення змісту і результатів кожної слідчої дії [7, с. 11].

Водночас, огляд характеризується меншою «суворістю» і у більшості випадків неконфліктністю та добровільним характером. Погоджуючись 3 думкою В. Зеленецького та А. Аобойка про те, що з метою підвищення ефективності кримінального переслідування у законодавство слід ширше впроваджувати спрощені форми провадження, які здатні забезпечити економію сил і засобів відповідних органів [8, с. 57], пропонуємо у майбутньому внести зміни до кримінального процесуального законодавства щодо запровадження спрощеного порядку оформлення протоколу огляду, однак не відмовившись від його складання взагалі.

3. Час проведення. Загальною рисою огляду і обшуку є заборона їх проведення у нічний час (з 22 до 6 годин). Спільними для обох 
цих дій є і виняткові випадки, коли вони можуть проводитися у нічний час, а саме коли затримка в їх проведенні може призвести до втрати слідів кримінального правопорушення ( ч. 4 ст. 233 КПК України) [4]. Так, 3 метою встановлення обставин вчиненого, виявлення та фіксації ймовірних слідів, при надходженні інформації про кримінальне правопорушення у нічний час, огляд місця події має бути проведений негайно. А особистий обшук особи здійснюється невідкладно після затримання, незалежно від часу доби, 3 метою виявлення предметів, які є речовими доказами, або вилучені з обігу чи таких, якими особа може завдати шкоди здоров'ю собі чи оточенню.

Серед відмінних рис між оглядом та обшуком у кримінальному досудовому провадженні нами виділені наступні:

1) Обов'язковість примусу та його характер. У більшості наукових дослідженнях на таку рису як примусовий характер, науковці вказують як на відмінну між оглядом та обшуком. Так, Б.М. Дердюк [9, с. 174], О. Зарубенко [10, с. 46], В.В. Горошко [6, с. 57] вказують на те, що відмінною рисою обшуку є пошуковий примусовий характер під час його проведення. В.В. Вапнярчук зазначає, що огляд найменше шкодить правам та інтересам громадян, адже під час огляду, як правило, здійснюється спостереження об'єктів, до яких є вільний доступ, що виключає примусові пошукові дії [11, с. 76].

Саме питання застосування примусу під час проведення огляду та обшуку можна розглядати у різних значеннях. Так, у теорії кримінального процесу є наукові дослідження 3 приводу можливого застосування під час проведення окремих слідчих дій, зокрема освідування фізичного впливу [12], або ж спеціальні засоби [13, с. 163].

Ми розглядаємо примусовий характер при проведенні огляду та обшуку у наступному значенні - як можливість їх проведення без згоди на це особи, права чи законні інтереси якої можуть бути обмежені чи порушені. До таких осіб можна віднести власника житла чи іншого володіння особи, де проводиться обшук чи огляд, володільця речі, яку буде піддано огляду, саму обшукувану чи освідувану особу.
В окремих випадках огляд може мати примусовий характер, зокрема у разі його невідкладного проведення, застосування заборони щодо залишення місця огляду до його закінчення та здійснення примусового освідування [14], однак зауважимо, що це є винятковими випадками, на відміну від обшуку, де застосування примусу буде у будь якому випадку.

Отже, розглядаючи про характер примусу під час огляду та обшуку слід зазначити, що під час обшуку він має обов' язковий (постійний) характер, а під час огляду - винятковий (епізодичний) характер

Крім того, примусовий характер проведення огляду та обшуку, проявляється у доступності до об'єктів для їх дослідження з метою виявлення відомостей. Погоджуючись 3 думкою А.В. Захарко, у найпростішому розумінні огляду - це «що бачу, те й пишу (та фіксую на технічний засіб)» [15, с. 397]. При огляді, на відміну від обшуку, не можуть застосовуватися активні примусові пошукові діï, наприклад, примусове відкриття зачинених дверей, шухлядок, розбирання стелі, плит тощо. Підтвердженням цього є постанова ВС від 26 лютого 2019 року, справа№ 266/4000/14-к провадження № 514505км18, у якій ВС дав оцінку огляду місця події домоволодіння ОСОБА і зазначив, що під час цієї слідчої дії відкривалися панелі розташовані на стелі, оглядалися вбудовані у стіну шафки та інші меблі, що є ознакою обшуку. Тому за обставин цієї справи огляд місця події фактично є обшуком [16].

Аргументами на користь того, що при огляді, на відміну від обшуку, не може бути здійснено дослідження недоступних об'єктів ,є постанова ВС від 22 травня 2018 року, справа № 662/1113/15, провадження № 51879км18, у якій ВС скасував вирок першої та апеляційної інстанції у зв'язку з визнання недопустим протоколу огляду місця події, так як за оцінкою ВС під виглядом огляду місця події у володінні засудженого фактично було проведено обшук. Цей висновок випливає 3 того, що під час цієї слідчої дії здійснювалося проникнення до місць, недоступних для звичайного спостереження.

2. Можливість проведення до Единого реєстру досудових розслідувань (далі - СРДР). 


\section{Кримінальне право, кримінальний процес та криміналістика}

Огляд та обшук відрізняються між собою і часом їх проведення. Відповідно до ч. 3ст. 214 КПК України до внесення відомостей у ЕРДР допускається проведення виключно огляду місця події [4].

Про можливість проведення обшуку тільки після внесення відомостей до ЕРДР наголошує адвокат У. Красовська, роз'яснюючи різницю огляду та обшуку [18].

Розглянемо можливість проведення огляду та обшуку до внесення відомостей до ЕРДР житла чи іншого володіння особи. Хоча у КПК України чітко не передбачено можливості проведення обшуку до ЕРДР, однак проаналізувавши ч. 3 ст. 233 КПК України про право слідчого, прокурора у невідкладних випадках до постановлення ухвали слідчого судді увійти до житла чи іншого володіння особи, звернувшись після здійснення таких дій до слідчого судді з клопотанням про проведення обшуку, можна зробити висновок про можливість його проведення до ЕРДР у випадках, передбачених вказаною нормою. Тож проводячи розмежування між огляду та обшуком у частині часу проведення, ми вважаємо за необхідне, що обшук проводиться після внесення відомостей до ЕРДР, окрім обшуку житла чи іншого володіння особи у невідкладних випадках, передбачених у ч. 3 ст. 233 КПК України.

Щодо обшуку особи, то проведення цієї слідчої дії до внесення відомостей до ЕРДР у КПК України не передбачено. У вище зазначеній постанові ВС від 21.01.2020 року, справа № 381/2316/17 ВС зауважив, що у кримінальному процесуальному законі не передбачено можливості проведення такої слідчої дії як особистий обшук до внесення до ЕРДР відомостей про скоєне кримінальне правопорушення [19].

\section{Висновки}

Розглянувши співвідношення між оглядом та обшуком у кримінальному досудовому провадженні, можна зробити висновок про те, що між ними є чимало спільних рис, таких як мета, протокольна форма фіксації, час проведення. Однак, між вказаними слідчими (розшуковими) діями існують і значні відмінності, зокрема, щодо обов'язковості примусу та його характеру, можливості проведення огляду до ЕРДР.

Подальшими напрямами наукових розвідок можна визначити такі: 1) розкриття співвідношення суб'єктів проведення огляду та обшуку; 2) з'ясувати питання стосовно оформлення процесуального рішення щодо проведення огляду та обшуку.

\section{Мітература}

1. Вирок Ставищенського районного суду Київської області від 16.01.2019 року : провадження № 1-кп/378/4/19. URL: https://reyestr. court.gov.ua/Review/79204316 (дата звернення 10.11.2020).

2. Постанова Верховного Суду від 21.01.2020 року : справа № 381/2316/17. URL: http://reyestr.court.gov.ua/Review/87179214 (дата звернення 12.11.2020).

3. Постанова Верховного Суду від 08.04.2020 року : справа №447/1765/16к провадження № 51-4968км 19 . URL: https://protocol.ua/ua/postanova k k s_v p_vid_08_04_2020_roku_u

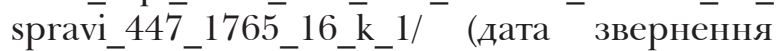
$16.11 . \overline{2} 020 \overline{)}$.

4. Кримінальний процесуальний кодекс України : Закон України від 13.04.2012 р. № 4651-VI. Дата оновлення: 23.05.2020. URL:https://zakon.rada.gov.ua/laws/show/465117 (дата звернення: 30.10.2020).

5. Литвинчук О.I., Сорока М.С., Колесников I.В. Електронні докази. Обшук. Частина 1 : посібник для адвокатів. Х.: Фактор, 2020. $80 \mathrm{c}$.

6. Горошко В.В. Тимчасове вилучення майна (кримінальний процесуальний аспект) : дис. ... канд. юрид. наук : 12.00.09. Одеса, 2019. 245 с.URL: http:// oduvs.edu.ua/wp-content/uploads/2016/06/ Disertatsiya_Goroshko_V.V..pdf (дата звернення 16.11.2020).

7. Бацько I.M. Протоколи слідчий дій як джерела доказів у кримінальному процесі. : автореф. дис. ... канд. юрид. наук : 12.00.09. Київ, 2003. 20 с.

8. Зеленецький В., Лобойко Л. Загальні напрями підвищення ефективності діяльності органів кримінального переслідування. Право Украӥни. 2009. № 2. С. 52-59 


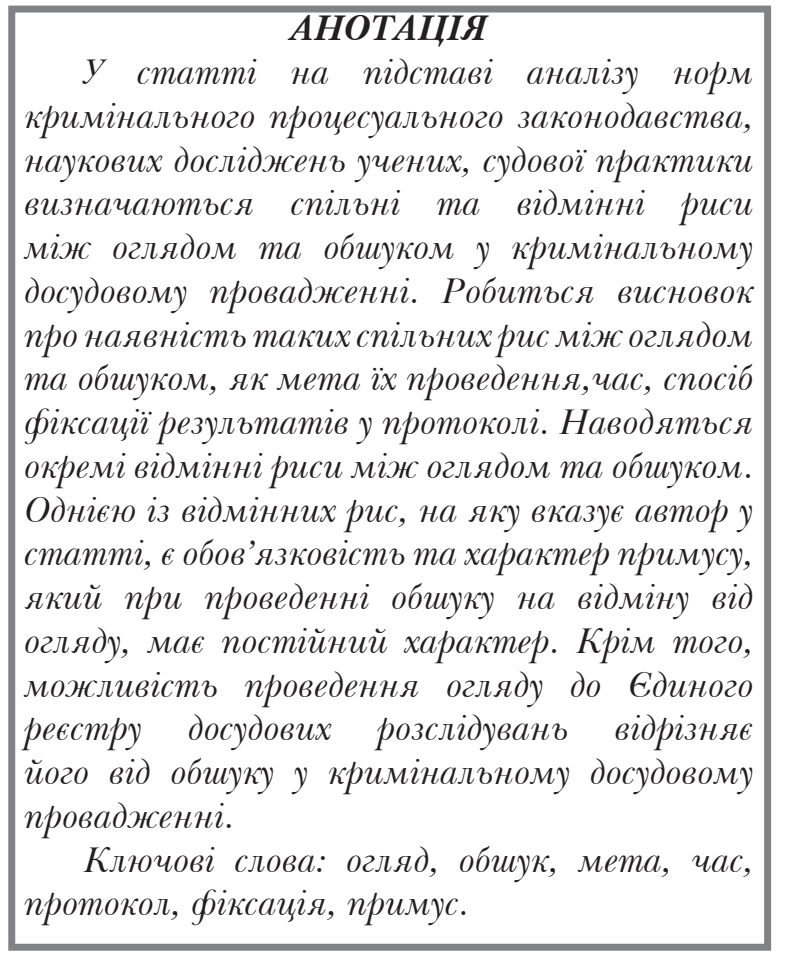

9. Дердюк Б.М. Співвідношення огляду з іншими слідчими (розшуковими) діями. Прикарпатсъкий юридичний вісник. Випуск 2(8). 2015 C. $173-176$.

10. Зарубенко О. Співвідношення огляду з іншими процесуальними діями за КПК України. Закон и жизнъ. 2013. № 3. С. 45-48.

11. Вапнярчук. Поняття і система слідчих (розшукових) дій . Науковий вісник Херсонсъкого державного університету . 2018. Випуск 2. Том. 2 с. 73-77.

12. Аук' янчиков С.Д., Аук'янчиков Б.С. Застосування примусу у процесі освідування. Часопис Начіонального університету «Острозька академія». Серія «Право». 2016. №1(13). URL: http://j.oa.edu.ua/articles/2016/n1/16lydvpo. pdf. (дата звернення 26.10.2020).

13. Ряшко О.В. Демків М.О., Корпан I.М. Освідування і кримінальному провадженні: сутність і межі процесуального примусу. Право і суспільство. 2019. № 1 ч. 2. С. 159-164.

14. Аучко О.А. Щодо можливості застосування примусу під час огляду. Сучасні проблеми правоохоронної діяльності та підготовки пробільних фахівиів: матеріали наук.-практ. семінару (м. Одеса, 6 листопада 2020 р.)

15. Захарко А.В. Підстави проведення слідчим ОВС у кримінальному процесі огляду транспортним засобу, що перебуває у во- лодінні особи. Науковий вісник АДУВС. 2013. № 2 C. $395-405$.

16. Постанова Верховного Суду від 26 лютого 2019 року : справа № 266/4000/14-к провадження № 51-4505км18,. URL: https://protocol.ua/ru/postanova_kks_vp_vid_26_02_2019_ roku_u_spravi_266_4000_14_k/ (дата звернення $1 \overline{5} . \overline{1} 1.2020)$.

17. Постанова Верховного Суду від 22 травня 2018 року : справа № 662/1113/15 провадження № 51-879км18). URL: https://protocol.ua/ru/postanova kks vp vid 22052018 roku_u_spravi 662_1113_15/ (дата звернення 15.11.2020).

18. Красовська У. Обшук і огляд: розмежування та підстави проведення. URL: https:// jurliga.ligazakon.net/ua/news/199157_obshuk-oglyad-rozmezhuvannya-ta-pdstavi-provedennуa (дата звернення 13.11.2020).

19. Постанова Верховного Суду від 21.01.2020 року : справа № 381/2316/17 BC. URL: https://zakononline.com.ua/courtdecisions/show/87179214 (дата звернення 13.11.2020).

Luchko Oksana State Institution "Kryzyi Rih Academy of Patrol Police", cycle of general legal dis-

\section{RELATIONSHIP BETWEEN EXAMINATION AND SEARCH IN CRIMINAL PRE-TRIAL PROCEEDINGS}

In the article on the basis of the analysis of norms of the criminal procedural legislation, scientific researches of scientists, judicial practice the general and distinctive features between inspection and search in criminal pre-trial proceedings are defined. It is concluded that there are such common features between the inspection and the search, as the purpose of their conduct, time, method of recording the results in the protocol. There are some distinctive features between the inspection and the search. One of the distinguishing features pointed out by the author in the article is the necessity and nature of coercion, which, in contrast to the search, is permanent In addition, the possibility of conducting a review of the Unified Register of Pretrial Investigations distinguishes it from a search in criminal pre-trial proceedings.

Key words: inspection, search, purpose, time, protocol, fixation, coercion. 